\title{
A medieval fallacy: the crystalline lens in the center of the eye
}

\author{
This article was published in the following Dove Press journal: \\ Clinical Ophthalmology \\ 8 April 2016 \\ Number of times this article has been viewed
}

\section{Christopher T Leffler \\ Tamer $\mathrm{M} \mathrm{Hadi}^{2}$ \\ Akrithi Udupa' \\ Stephen G Schwartz \\ Daniel Schwartz'}

'Department of Ophthalmology, Virginia Commonwealth University, Richmond, VA, ${ }^{2}$ Graduate School of Medicine, University of Tennessee Medical Center, Knoxville, TN, ${ }^{3}$ Bascom Palmer Eye Institute, University of Miami Miller School of Medicine, Miami, FL, USA
Correspondence: Christopher T Leffler Department of Ophthalmology, Virginia Commonwealth University, 40 I N I I th St, Box 980209, Richmond, VA 23298, USA

$\mathrm{Tel}+\mathrm{I} 8048289315$

Fax +18048281010

Email chrislefflermd@gmail.com
Objective: To determine whether, as most modern historians have written, ancient Greco-Roman authors believed the crystalline lens is positioned in the center of the eye.

Background: Historians have written that statements about cataract couching by Celsus, or perhaps Galen of Pergamon, suggested a centrally located lens. Celsus specifically wrote that a couching needle placed intermediate between the corneal limbus and the lateral canthus enters an empty space, presumed to represent the posterior chamber.

Methods: Ancient ophthalmic literature was analyzed to understand where these authors believed the crystalline lens was positioned. In order to estimate where Celsus proposed entering the eye during couching, we prospectively measured the distance from the temporal corneal limbus to the lateral canthus in 30 healthy adults.

Results: Rufus of Ephesus and Galen wrote that the lens is anterior enough to contact the iris. Galen wrote that the lens equator joins other ocular structures at the corneoscleral junction. In 30 subjects, half the distance from the temporal corneal limbus to the lateral canthus was a mean of $4.5 \mathrm{~mm}$ (range: $3.3-5.3 \mathrm{~mm}$ ). Descriptions of couching by Celsus and others are consistent with pars plana entry of the couching needle. Anterior angulation of the needle would permit contact of the needle with the lens.

Conclusion: Ancient descriptions of anatomy and couching do not establish the microanatomic relationships of the ciliary region with any modern degree of accuracy. Nonetheless, ancient authors, such as Galen and Rufus, clearly understood that the lens is located anteriorly. There is little reason to believe that Celsus or other ancient authors held a variant understanding of the anatomy of a healthy eye. The notion of the central location of the lens seems to have arisen with Arabic authors in 9th century Mesopotamia, and lasted for over 7 centuries.

Keywords: anatomy, medical history, crystalline lens, cataract couching

\section{Introduction}

The crystalline lens is located in the anterior aspect of the human eye. It is well established that medieval anatomists mistakenly believed that the lens was located in the exact center of the eye, including in the anteroposterior dimension. Historians over the last century seem to be united in writing that the medieval anatomists inherited this idea from the ancient Greco-Roman authors, ${ }^{1-35}$ though the historians do not seem to agree which ancient author or text established this teaching. Most historians cite no specific textual passage to support the theory that ancients described the lens as being located centrally. ${ }^{3-11,13-19,22-35}$ Some historians have attributed this view to Galen of Pergamon (c. AD 129-199), a prominent Greek physician in the Roman empire. ${ }^{15,16,18-32}$ In contrast, other historians report that Galen and Rufus of Ephesus (AD 80-150), the premier anatomist of the era, positioned the lens anteriorly. . $2,6,9,12-14,36^{-1}$ According to this view, the lens was described as being located centrally in the works 
of the Roman encyclopedist Cornelius Celsus (c. 25 BC to AD 50). ${ }^{1-18}$ Some historians attribute the teaching of the centrally positioned lens to the Alexandrian anatomist Herophilus (325-255 BC $)^{25,34}$ or are not specific about which ancient authors promoted this view. ${ }^{35}$

Did ancient Greco-Roman authors really think that the lens was located in the center of the eye? If so, why do modern historians not agree on which textual passage or even which ancient author supported this idea? In order to answer these questions, we reviewed ancient and medieval texts to determine when the idea of the central lens originated. First, we present evidence that the ancient Greco-Roman authors did know that the lens is located anteriorly.

Second, we analyze the reasons that modern historians have written that ancient authors described the lens as being located centrally. In this section, we present a small prospective human subject study regarding the couching technique of Celsus, because this technique has been deemed relevant by one influential historian.

Third, we show that during the medieval Arabic period, the lens was clearly described as being in the exact center of the eye. Finally, we review the correct anterior placement of the lens during the Renaissance, and the importance of this question in the history of medicine.

Throughout the text, we quantify the anteroposterior location of the lens by the lens location ratio (LLR), defined as the distance from the anterior-most aspect of the cornea to the lens equator divided by the eye's axial length. For instance, an LLR of 0.5 characterizes a central lens, while the actual human eye, according to the modern understanding, has an LLR of 0.20 (Figure 1). ${ }^{37}$

\section{Ancient understanding of the anterior lens}

Celsus' understanding of the eye has been depicted as including an anteriorly positioned lens (Figure 2).$^{38}$ In addition, many historians, such as Magnus, Hirschberg, Shastid, and Eastwood, have written that Rufus and Galen understood that the lens was located anteriorly (Figures 3 and 4). 1,2,6,9,12-14,36 What evidence supports the idea that the ancients knew that the lens is positioned anteriorly?

\section{Discovery through dissection}

The ancient authors discovered the lens through anatomic dissection. They would have seen where the lens was located when they opened the eye. Of course, there was a time which preceded dissections. Hippocrates (c. 460-370 BC), considered to be the father of Western medicine, noted that the eye contained viscous fluids, which could spill out

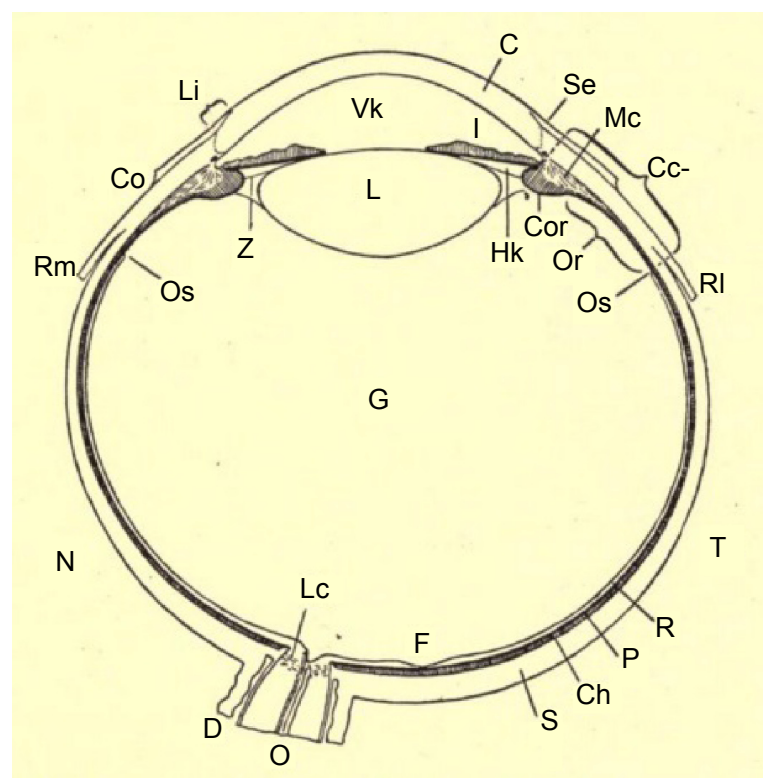

Figure I The lens $(L)$ positioned anteriorly in the schematic horizontal section of the right eye. ${ }^{37}$

Abbreviations: C, cornea; Cc, corpus ciliare; Ch, chorioidea; Co, conjunctiva sclerae; Cor, corona ciliaris; D, dural sheath; F, fovea centralis; G, vitreous; Hk, posterior chamber; I, iris; Lc, lamina cribrosa; Li, limbus; Mc, musculus ciliaris; N, nasal side; $\mathrm{O}$, nervus opticus; Or, orbiculus ciliaris; Os, ora serrata; $\mathrm{P}$, pigment epithelium; $\mathrm{R}$, retina; $\mathrm{RI}$, musculus rectus lateralis; $\mathrm{Rm}$, musculus rectus medialis; $\mathrm{S}$, sclera; $\mathrm{Se}$, sulcus sclerae externus; $\mathrm{T}$, temporal side; $\mathrm{Vk}$, anterior chamber; $\mathrm{Z}$, zonula ciliaris.

after trauma, and which, if cooled, resembled "transparent incense." This "incense" might have represented the crystalline lens, ${ }^{1}$ although there is no way to be sure. Moreover, the substance was not associated with any particular region of the eye.

Celsus wrote that Herophilus dissected condemned criminals before they died. Scholars have debated the veracity of this claim, but the historian Heinrich Staden argues for its plausibility.$^{39}$ In any event, it is accepted that Herophilus dissected humans. ${ }^{40}$ Herophilus' ophthalmic works have not survived, but some of his ophthalmic observations are known from surviving fragments. Celsus noted that Herophilus coined the name arachnoidem for the retina (7.7.13), ${ }^{38}$ due to its resemblance to a cobweb. ${ }^{39}$ Herophilus also mentioned that the iris surface is rougher on the interior (posterior) side..$^{39,41}$ Given the level of detail of his observations, it seems likely that Herophilus would have seen the crystalline lens, though no record of this observation has survived.

Subsequent authors in the early Common Era, such as Celsus and Demosthenes Philalethes, mentioned the crystalline lens. ${ }^{42}$ Although human dissection was outlawed after the Alexandrian period, ${ }^{40}$ Rufus based his internal anatomy on dissections of the monkey, ${ }^{43,44}$ and Galen dissected Barbary macaques (Macaca sylvanus). ${ }^{44,45}$ Both Rufus ${ }^{43,44}$ and Galen ${ }^{45}$ wrote that the anatomy of the 


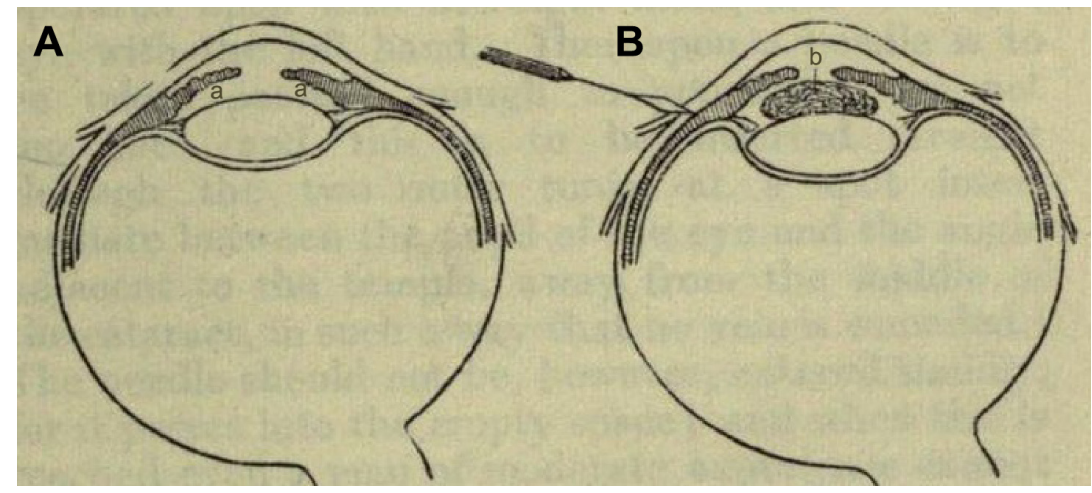

Figure 2 The anatomy of the eye with an anterior lens according to Walter Spencer's 1938 interpretation of Celsus' writings (lens location ratio 0.23). ${ }^{12}$

Notes: (A) Depicts the healthy eye with the locus vacuus, or empty space, denoted "a", between the lens and iris. (B) Depicts the eye during couching, with a suffusion, or cataract, denoted "b", anterior to the lens.

monkey most closely corresponded with that of humans. Galen wrote in the second book of De Usu Partium: "I am now explaining the structures actually to be seen in dissection ... Hence, if anyone wishes to observe the works of Nature, he should put his trust not in books on anatomy but in his own eyes ...." ${ }^{46}$ Galen extensively described dissection of the eye..$^{47,48} \mathrm{He}$ not only described his dissection technique, but added that one who has never seen an eye being dissected is "an ignoramous" who can be deceived and mislead. ${ }^{48}$

Could dissection poorly represent the living human anatomy? Macaque lenses are located anteriorly (LLR $0.22-0.23$, Figure 5). ${ }^{49}$ Galen also performed some functional

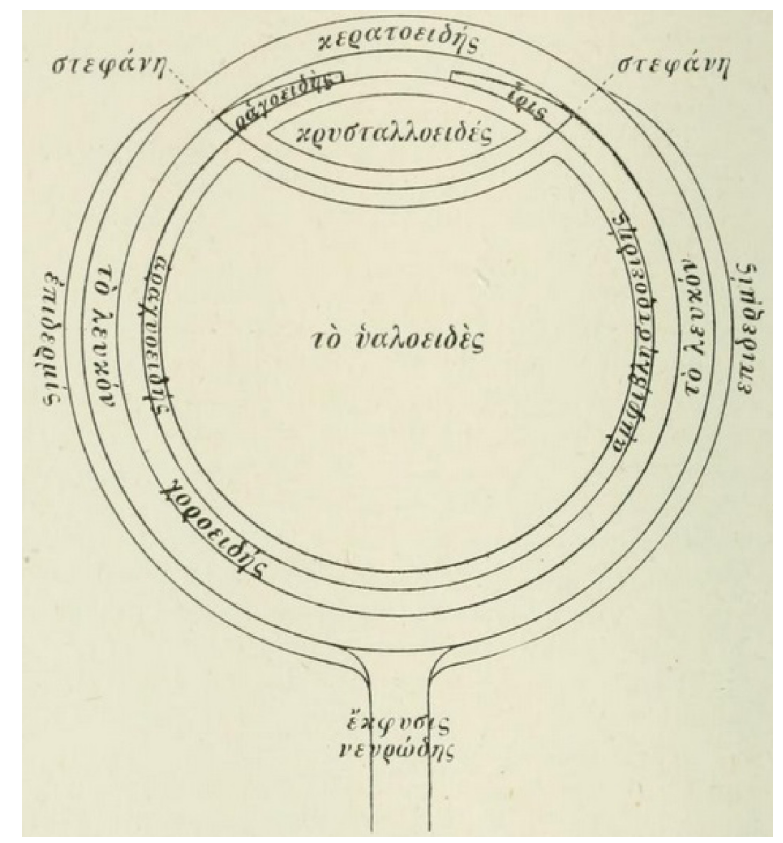

Figure 3 The anatomy of the eye, with an anterior lens (lens location ratio 0.18 ), according to a modern interpretation of the writings of Rufus of Ephesus. ${ }^{13}$ vivisection experiments on pigs. ${ }^{50}$ The lens of a pig is thicker (LLR 0.33-0.35, Figure 6) ${ }^{51}$ Still, it seems unlikely that one would confuse the lens of either animal with a central lens. Moreover, as noted earlier, the ancients recognized monkeys as having anatomy most analogous with humans.

The lens could be dislocated from injury or during specimen preparation, but Galen clearly described the lens attaching circumferentially at its equator to the corneoscleral junction, as discussed below in the section entitled "Meeting of the lens with the cornea". Leonardo da Vinci (1452-1519) proposed boiling eye specimens, which disrupts the lens zonules and dislocates the lens posteriorly. ${ }^{52}$ However, this preparation technique was not described in antiquity.

\section{Lens contact with the iris}

According to both Rufus and Galen, the crystalline lens is anterior enough to touch the iris. An anonymous letter attributed to Rufus noted that: "The anterior half of the crystalline lens lies on the hole of the iris." ${ }^{12,41}$ Galen wrote of " $\ldots$ the roughnesses on the inner side of the tunic [the iris] that surrounds the crystalline humor. For these are moist and soft like a sponge, and where they touch the crystalline humor ..." (X.II.69) ${ }^{47} \mathrm{He}$ also wrote: “... consider the nature of the grapelike tunic [the iris]; for the part of it touching the crystalline humor ..." (X.II.74). ${ }^{47}$ Moreover, "The covering [the iris] next to this is full of veins, soft, dark, and perforated; soft, in order not to cause pain when it touches the crystalline humor" (X.II.75). ${ }^{47}$

Rufus and Galen might have been correct about the iris touching the lens. The central iris does appear to touch the lens, because the width of the iris-lens channel is narrower than can be resolved with current imaging techniques. ${ }^{53,54}$ Obviously, there must be at least transient or local separation between the iris and lens in order for aqueous to flow into the anterior 


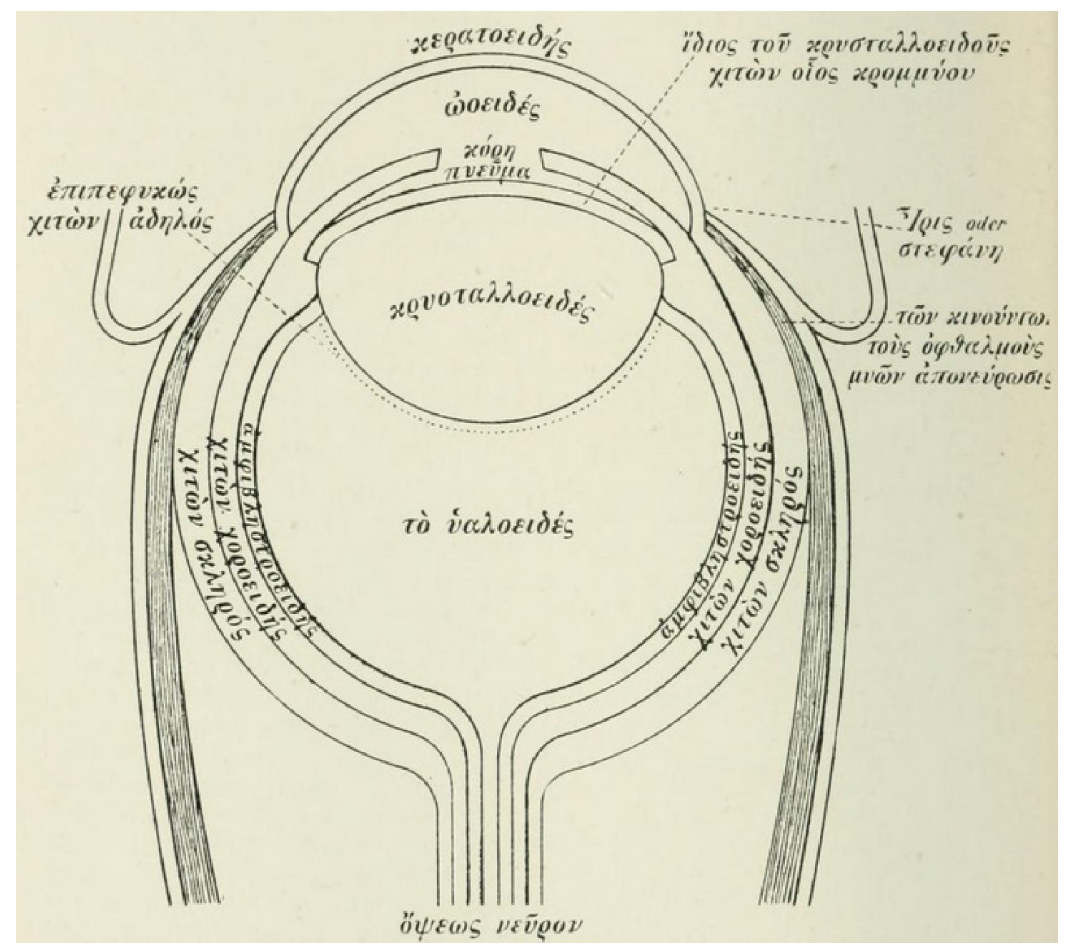

Figure 4 The anatomy of the eye, with an anterior lens (lens location ratio 0.30), according to Hugo Magnus' interpretation of Galen's writings. ${ }^{2}$

chamber. The mathematical model of a steady, uniform flow through a homogeneous iris-lens channel can provide useful theoretical insights. ${ }^{55}$ Nonetheless, it is conceivable that the iris does actually touch the lens at certain locations or times. ${ }^{54} \mathrm{Such}$ contact could account for the patterns of discrete, localized

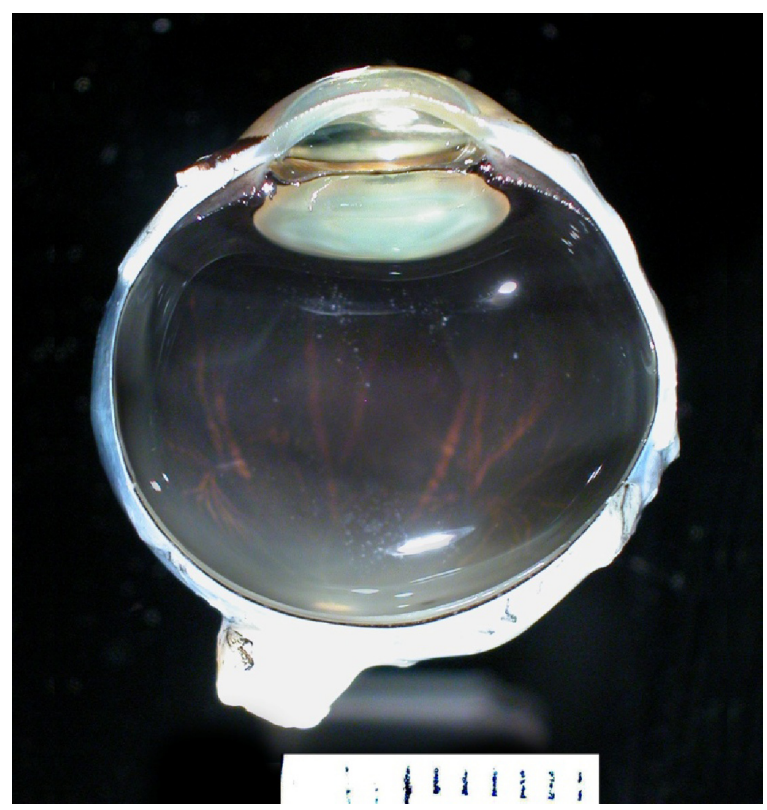

Figure 5 The macaque eye in cross section.

Notes: Image courtesy of Richard Dubielzig, DVM, of the University of Wisconsin. The lens is located anteriorly: this specimen's lens location ratio of 0.22 is similar to that of a composite eye (0.23). aqueous flow seen at the pupillary margin when fluorescein is instilled into the anterior chamber. ${ }^{54}$ Moreover, central iris-lens touch is suggested by posterior synechiae following inflammation, and by the absence of deposition of pseudoexfoliative material in areas of the mid-peripheral lens capsule.

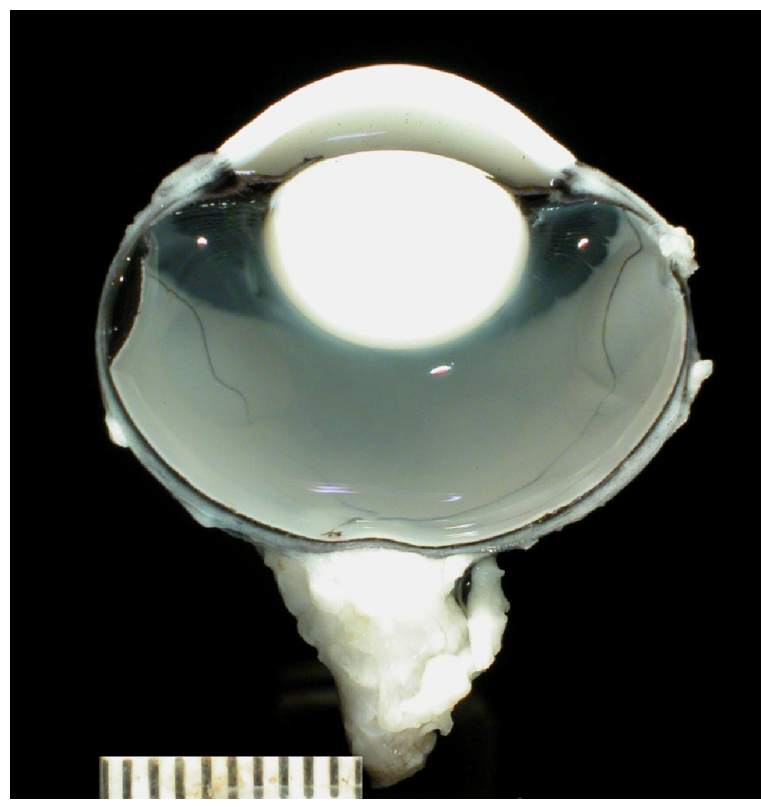

Figure 6 The eye of a pig in cross section.

Notes: Image courtesy of Richard Dubielzig, DVM, of the University of Wisconsin. The lens is thicker, but its equator still lies anteriorly. This specimen's lens location ratio of 0.35 is similar to that of a composite eye $(0.33)$. 


\section{Meeting of the lens with the cornea}

According to Galen, around the equator of the crystalline lens converged multiple ocular structures: the cornea, sclera, grapelike tunic (the iris), conjunctiva, vitreous, retina, choroid, and muscle tendons. He termed this region the iris, or the corona. Galen used the term iris, or rainbow, because during dissection, he could see various colors of the exposed structures (X.II.61) ${ }^{47}$ Elsewhere, Galen noted "By means of its maximum circumference, the lens enters into relation with the corona [corneo-sclerotic junction]. ${ }^{" 48}$ The fact that the cornea and the iris converged at this location indicates that this region was located anteriorly. The idea that all these structures meet is an oversimplification of the microscopic anatomy. ${ }^{37,56}$ However, the ancients did not have microscopes, and Galen's description approximated the gross appearance of the eye (Figures 1 and 5). This idea runs throughout his works on the anatomy of the eye. For instance, Galen wrote: “... where this hornlike tunic [the cornea] grows off from the iris [the ciliary region], it will seem to you to be very close to the crystalline humor, since all the humors and tunics of the eye are united in this region ..." (X.II.70-71). ${ }^{47}$

Paulus Aegineta (AD 625-690) quoted Galen's definition of this region: “... the place where all the coats of the eye unite. This place is called by some the iris [iptv, irin],

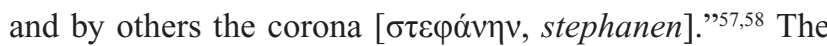

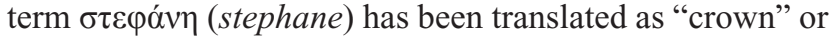
"wreath," encircles anything at the top, as if it were a crown." ${ }^{\circ 9}$ Readers may be familiar with the Biblical use of the term $\sigma \tau \dot{\varepsilon} \varphi \alpha v o \varsigma$ (stephanos) to describe a "crown" of thorns (eg, Matthew 27:29). ${ }^{60}$ Thus, Galen compared the cornea-iris-lens complex to a crown resting upon the top of the eye (Figure 5).

\section{Absence of ancient descriptions of lens centrality}

The crystalline lens was mentioned by multiple GrecoRoman and Byzantine authors: Celsus, ${ }^{38}$ Demosthenes Philalethes, ${ }^{39,42}$ Rufus, ${ }^{41}$ Galen, ${ }^{47,48}$ Oribasius (AD 325-403) ${ }^{61}$ Aetius of Amida (AD 502-574), ${ }^{62}$ Paulus Aegineta, ${ }^{57,58,63}$ and Theophilus Protospatharius (seventh century AD) ${ }^{64}$ In these writings, we have not found the statement that the crystalline lens is located in the center of the eye (Supplementary material).

At this point, one might wonder what controversy could possibly exist. After all, the ancient authors discovered the crystalline lens through dissection. They never wrote that the lens is located in the center of the eye. On the contrary, they correctly described the lens as being anterior enough to touch the iris and meet the cornea peripherally. And many prominent historians have accepted that authors such as Rufus, Galen, and Celsus placed the lens anteriorly.

\section{Claims of ancient belief in a central lens}

But the controversy persists because most historians agree that "someone" in antiquity originated the idea of the central lens. Many historians such as Stephen L Polyak and Max Meyerhof have stated that Galen described the lens as being located in the center of the eye. ${ }^{15,16,18-32}$ According to other historians, Celsus described the lens as being located centrally. ${ }^{1-18}$ What has given rise to these claims?

\section{The lens floating on the vitreous}

One passage may require some explanation, even though it has never been cited by historians as suggesting a central lens. Galen wrote that the union of the retina and lens "... forms a perfect circle, because, when this insertion is made from all sides into the middle [equator] of the crystalline body ... a circle necessarily results. This ... is the largest circle on the crystalline body and divides it into two parts." ${ }^{97}$

Galen added "It was reasonable too to keep the vitreous humor from passing forward at this same circle, so that thanks to it the crystalline humor rests in the midst of the vitreous like a sphere cut in half in water." ${ }^{47}$ Here, Galen is indicating that the junction of the lens equator and retina (ie, the lens zonules) holds the vitreous posteriorly. This junction allows the lens to rest in the vitreous in the same manner as a sphere floating in water, so that the posterior half of the lens is submerged in the vitreous, while the anterior half of the lens is anterior to the vitreous (Figure 5).

The analogous passage from Oribasius, who took his anatomy from Galen, has been translated into French, and can be rendered:

As the implantations of which we just spoke are everywhere around the middle (circumference) of the crystalline, which is round, it necessarily results in the formation of a perfect circle, and this circle is the greatest circle of the crystalline, and divides it [consequently] into two equal parts. It is reasonable to prevent, at the level of this circle, the vitreous humor from advancing, a provision which makes the crystalline float in the middle on this humor, like a sphere cut in two by water. ${ }^{61}$

The authors compare the lens "floating" on the vitreous to a sphere floating on water (with the waterline dividing the sphere - ie, the lens - in two). 


\section{The location of cataract}

All the Greco-Roman authors, including Celsus and Galen, erroneously thought that a couching needle displaced a pathologic structure (termed hypochyma or suffusio) which had formed anterior to the lens. ${ }^{42}$ Historians have not written that this error proves that the ancients thought the lens was located centrally, but we thought it best to address this error nonetheless. Put simply, the understanding that opacities can form anterior to the lens does not require belief that the lens is in the center of the eye. For instance, the translation of Celsus by Spencer depicted an anterior lens accompanied by an even more anterior opacity (Figure 2) ${ }^{38}$ Similarly, in the early 1700s, several French physicians realized that couching typically displaced the lens, which had opacified. ${ }^{65}$ Numerous oculists, such as John Thomas Woolhouse, objected, and at least initially maintained the ancient teaching that an opacity anterior to the lens was displaced by couching. But Woolhouse and others did not argue their case on the grounds that the lens was in the center of the eye. ${ }^{65,66}$ Today, we know that the lens is located anteriorly, but we still recognize that there can exist even more anterior opacities, such as pupillary membranes, fibrin, hyphema, and hypopyon. In summary, a recognition of opacities anterior to the lens does not require a central lens.

\section{Galen on movement of the couching needle}

Polyak cited the following passage as evidence that Galen described the lens as located in the center of the eye. ${ }^{20}$ After noting that cataracts develop between the cornea and lens, Galen wrote: "the instrument ... when moved around through the large, free space, up, down, to the sides, and in short, circularly in all directions, does not touch either of the bodies in question because the distance between them is very great" (X.II.71). ${ }^{47}$ From the context, the translator noted that "the bodies in question" referred to the cornea and lens. ${ }^{47}$ Polyak described this passage as a "contradiction" because Galen in the same chapter described an anterior lens, as we reviewed earlier. However, this passage does not require a central lens. For instance, if a surgeon today stated "I prefer doing phacoemulsification on myopes because I have a lot of room to work in the anterior chamber without damaging the corneal endothelium," we would not infer that the surgeon thought that the lens was centrally located. Galen's passage on couching is ambiguous, while his statements that the lens contacts the iris and meets with the cornea peripherally are not.

\section{The couching technique of Celsus}

Historians have frequently written that Celsus placed the lens centrally. This idea seems to originate with the historian Hugo Magnus, who in 1901 published a figure purporting to summarize Celsus' anatomical understanding (Figure 7). ${ }^{2}$ Magnus' figure has been accepted by most historians ${ }^{3-18}$ and assumed to reflect the views of not only Celsus, but also his "contemporaries." 7,8 The American Academy of Ophthalmology Basic and Clinical Science Course states that the figure was drawn by Celsus himself. ${ }^{11}$

In fact, Celsus never made any specific statement about the anteroposterior location of the lens. ${ }^{38,67,68}$ Magnus explained ${ }^{1}$ that his drawing was motivated by the following passage by Celsus describing cataract couching:

... the needle ... must be thrust in ... in the middle part betwixt the black of the eye [ie, the limbus] and the external angle [ie, the lateral canthus, medio loco inter oculi nigrum et angulum tempori propiorem ] ... it comes into a void space [inani loco] $(7.7 .14) .^{38,67}$

Celsus had earlier written that this empty space [locus vacuus] was located "at the spot where the pupil is" (7.7.13). ${ }^{38}$ This space has been interpreted to be the posterior chamber. Magnus wrote that because the couching needle was thought

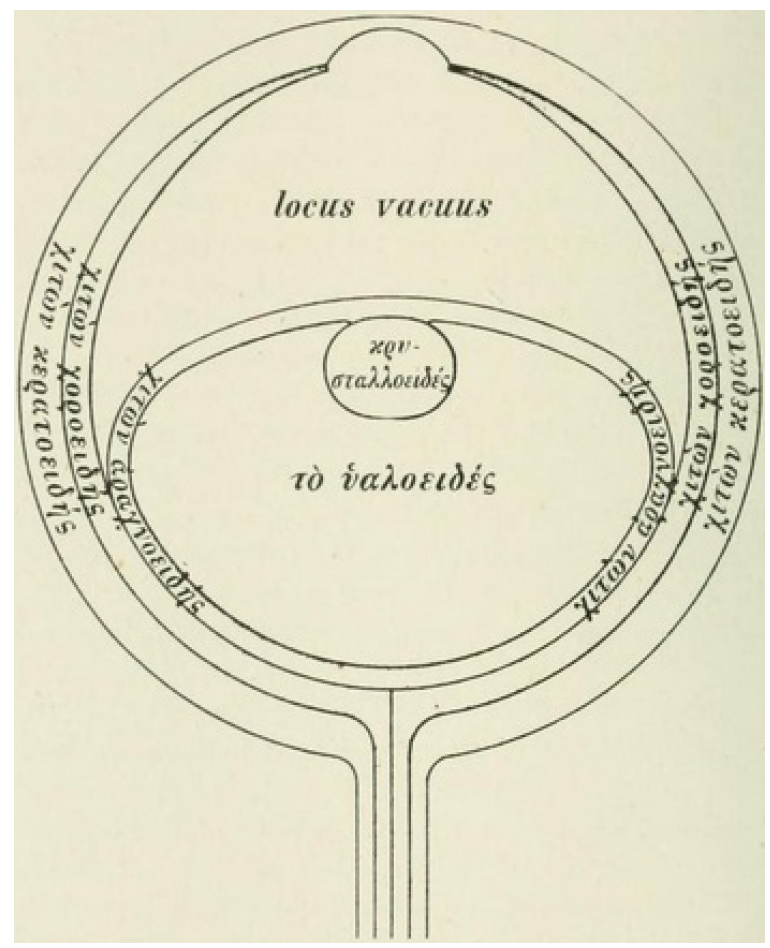

Figure 7 The anatomy of the eye, with the central lens, according to Hugo Magnus' interpretation of Celsus' writings (lens location ratio 0.47). ${ }^{7}$ 
to enter the posterior chamber, "one may well assume" that Celsus' teaching "corresponds to the concepts of the relations held during the Middle Ages" that the lens is positioned in the center of the eye. ${ }^{1}$ However, Magnus did not provide anatomical measurements to define the placement of the couching needle. We therefore conducted a human subjects study to better understand the technique described by Celsus.

\section{Materials and methods}

This prospective study was approved by the Virginia Commonwealth University Office of Research Subjects Protection, was Health Insurance Portability and Accountability Act-complaint, and adhered to the tenets of the Declaration of Helsinki. In healthy adult volunteers who granted written informed consent, the distance from the temporal corneal limbus to the lateral temporal canthus of the right eye was measured with calipers. Subjects were instructed to look straight ahead at a distant target. Sex and race were recorded. Refraction spherical equivalent was estimated from spectacle lenses. Multivariable linear regression was used to determine predictors of the placement of the couching needle, according to the technique of Celsus.

\section{Results}

In 30 adult subjects (16 male, 14 female; 16 black, 14 white), the mean age was 46 years (standard deviation 15 years). Half the distance between the temporal corneal limbus and the lateral canthus was a mean of $4.5 \mathrm{~mm}$ (standard deviation $0.9 \mathrm{~mm}$, range: $3.3-5.3 \mathrm{~mm}$ ). By multivariable linear regression, the (half) distance averaged $4.0 \mathrm{~mm}$ in 60-year-old white female emmetropes, and tended to be greater by $0.2 \mathrm{~mm}$ in males, $0.2 \mathrm{~mm}$ in blacks, $0.1 \mathrm{~mm}$ for each decade younger, and $0.1 \mathrm{~mm}$ per 5 diopters of myopia. Only the association with age was statistically significant $(P=0.03)$. This association might relate to age-related changes of the eyelid or lateral canthus. In any event, the small magnitude of all the regression coefficients suggests that for each of the independent variables studied, the (half) distance (and predicted placement of the couching needle) does not tend to vary substantially.

\section{Interpretation of this prospective study}

Magnus assumed that Celsus believed in a central lens because Celsus implied that a couching needle placed in a manner which seemed to Magnus to be fairly posterior entered the posterior chamber. Thus, it seemed to Magnus that Celsus might have thought that the lens is located extremely posteriorly. Our experimental results show that Celsus' placement of the needle for couching would have typically been between 3.3 and $5.3 \mathrm{~mm}$ posterior to the limbus. This placement is consistent with a pars plana insertion. The pars plana extends approximately $6 \mathrm{~mm}$ posterior to the temporal corneal limbus in most adult eyes. (The ciliary body is on average $5.76 \mathrm{~mm}$ long in adults temporally, and the external distance from the limbus to the ora serrata is expected to be $0.3-0.4 \mathrm{~mm}$ greater. ${ }^{56}$ ) Although ancient authors would not have understood this anatomy, the ancients might have settled on this location empirically. More posterior placement would make it more difficult to reach the lens and might lead to vitreous hemorrhage or retinal detachment. More anterior placement might damage the iris or produce hemorrhage.

We agree with ophthalmic historians who have maintained that the border of the oculi nigrum represents the limbus., ${ }^{1,12}$ Oculi nigrum has been translated as "the black of the eye" ${ }^{67}$ or "the pupil.." 38,68 The term "pupil" is derived from the Latin pupilla for small person, because when gazing in another's eye, one sees one's minified reflection. ${ }^{69}$ Ancient Mediterranean languages arose in populations in which dark irides were common and, therefore, underlay the basic linguistic approach. ${ }^{42}$ When looking at an eye with a dark iris, the reflection is seen over the entire region of the iris and pupil and, therefore, the pupilla might correspond with this entire area. When Celsus defined mydriasin (mydriasis) as a dilatation of the pupilla, he meant that the pupil is dilated (6.37). ${ }^{38}$ On the other hand, when he referred to the pupillary (pupillae) color being either niger or caesius (7.13), ${ }^{38}$ he was referring to the iris. With respect to eye color, caesius typically represented light blue or gray. ${ }^{42}$

It may seem unusual that Celsus described a dark iris as black (niger), until we recall that English speakers described eye color more often as black than as brown well into the 19th century. ${ }^{69}$ When Celsus referred to an alteration in the "black part of the eye" (nigra pars oculi) as a poor prognostic indicator for surgery (7.13), ${ }^{38}$ he could have been referring to an abnormal shape of the iris, rather than the pupil, as the latter implies the former.

In summary, if Celsus had wanted to describe the pupillary margin, he probably would have used the term pupilla, as this is the only term he clearly used to describe the pupil. Most likely, oculi nigrum is best translated as "the dark part of the eye" and corresponds with the iris, plus, perhaps, the enclosed pupil. The variation in English translations possibly results from the absence of an English word to describe this entire area.

One possible uncertainty is whether Celsus' instruction meant to imply needle placement exactly halfway between 
the limbus and canthus, as Hirschberg held, ${ }^{12}$ or only approximately at this location. Celsus' phrase medio loco inter has been translated as "in the middle part betwixt," "at the intermediate point between," mediate between." ${ }^{38}$ Our measurements suggest that needle placement either exactly or approximately at the halfway point is consistent with pars plana insertion.

We asked volunteers to gaze straight ahead because neither Celsus, ${ }^{38}$ pseudo-Galen, ${ }^{70-72}$ Paulus Aegineta, ${ }^{57}$ or even Benevenutus Grassus over a millennium later ${ }^{73}$ described asking the patient to look nasally or temporally. Georg Bartisch gave a somewhat nuanced instruction in the 16th century: “... have him look directly ahead at the light or look toward your face. The patient turns and moves his eye a little toward his nose." ${ }^{\prime 4}$ Still, Bartisch's illustrations show patients looking straight ahead with the couching needle placed approximately halfway between the limbus and the lateral canthus (Figures 8 and 9). ${ }^{74}$

Another uncertainty relates to the angle of the needle. Modern ophthalmologists orient the needle posteriorly when performing intravitreal injections or creating sclerotomies, specifically to avoid contacting the lens. When performing couching, ancient surgeons must have oriented the needle more anteriorly (because they did contact the lens), but the exact angle is unknown. To the extent that the needle was oriented anteriorly, Magnus' implication that the needle tip could not have entered the posterior chamber (as described by Celsus) is weakened.

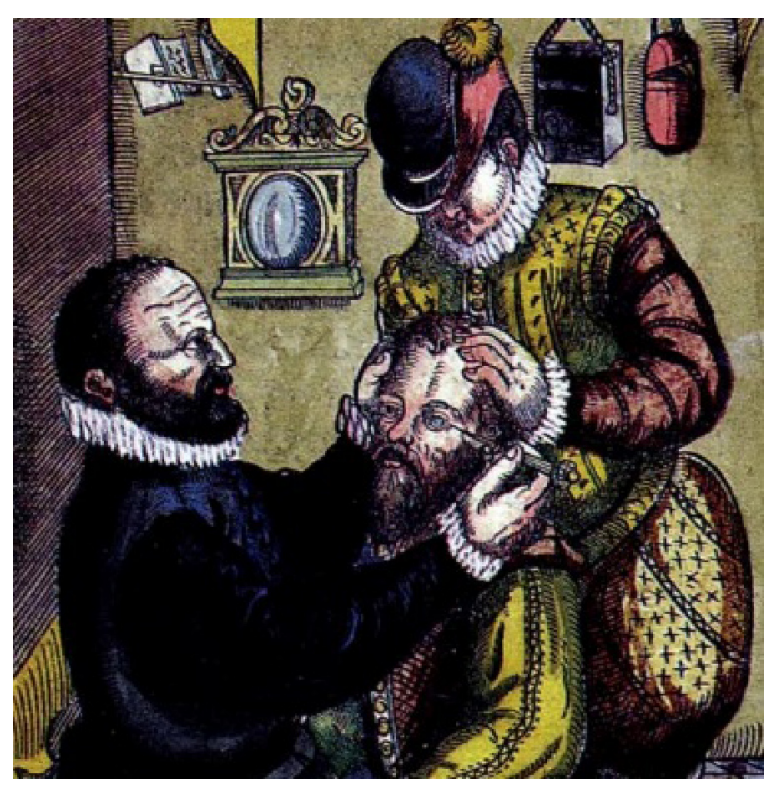

Figure 8 During cataract couching, as depicted by George Bartisch in 1583. Notes: The patient seems to be gazing straightahead. Copyright $(1$ 1 995.JPWayenborgh. Reproduced from Bartisch G, Blanchard DL (translator). Ophthalmodouleia. That is the Service of the Eyes. Ostend, Belgium: JP Wayenborgh; 1995:7-63. ${ }^{74}$

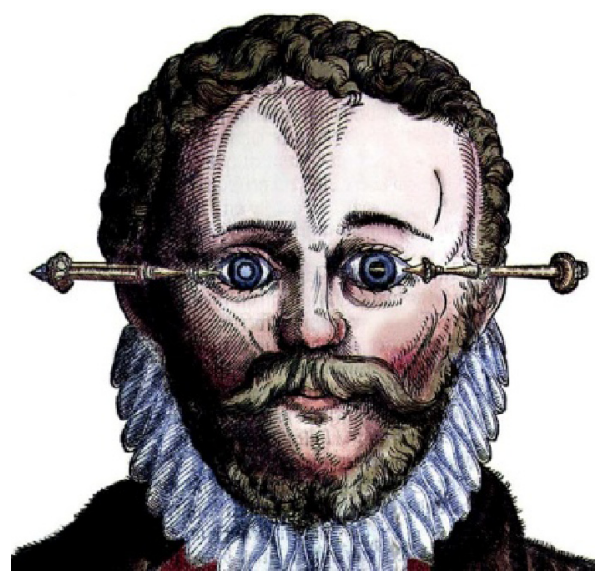

Figure 9 In couching of cataracts, as depicted by George Bartisch in 1583. Notes: The needle appears to be placed on the eye about halfway between the limbus and the lateral canthus, and then passes posterior to the iris. Copyright (C) 1995. JP Wayenborgh. Reproduced from Bartisch G, Blanchard DL (translator). Ophthalmodouleia. That is the Service of the Eyes. Ostend, Belgium: JP Wayenborgh; 1995:7-63. ${ }^{74}$

Scholars have debated whether Celsus actually practiced medicine. But there is agreement that Celsus was an encyclopedist who recorded the medical understanding and practices of Greek authors. Celsus does not describe a system of anatomy based on his own theories, experiments, or practice of medicine. He simply recorded the teachings and terminology of the Greeks.

\section{Other ancient descriptions of couching}

We might provide context and resolve ambiguities in Celsus' couching description by examining other Greek authors. One unknown author has been deemed "pseudo-Galen," because he adopted many of the Galenic teachings, and might have been a contemporary of Galen. ${ }^{75}$ The Introductio, seu medicus of pseudo-Galen records that when couching cataracts one

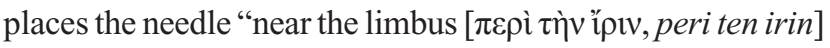
on the side of the temporal angle until (the instrument) reaches

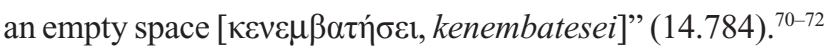
The phrase translated as "near the limbus" could have been translated quite literally as "peri-iris." The phrase "reaches an empty space" was expressed in medieval Latin as "penetrarit et loco vacuo," ${ }^{71}$ a phrase reminiscent of Celsus' writing.

The couching procedure is recorded in greater detail by Paulus Aegineta. ${ }^{57,58}$ Paulus states twice that he is relating Galen's technique. ${ }^{57}$ Paulus describes the placement of the needle: "at the distance from the part called the iris toward the small canthus, of about the size of the knob of the specillum [probe]." ${ }^{57}$ The needle is inserted until "we come to an

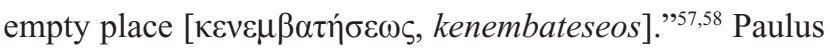
also relates that after the needle is inserted deeply enough to reach the pupillary margin, but before the cataract is displaced, "the copper of it [the needle] is seen through the 
transparency of the cornea." ${ }^{57}$ In order for the needle tip to be visible through the cornea, the needle must actually have passed through the posterior chamber and the iris-lens channel into the anterior chamber.

Thus, the ancient couching descriptions have some commonalities. Needle placement is some distance between the edge of the iris (the limbus) and the lateral canthus. This distance is defined with respect to the edge of the iris (the limbus) and was probably, therefore, closer to the limbus than the canthus. Although each description of needle placement is indefinite ("at a point intermediate between" 38 these structures, "near the iris," 71 and at a distance "the size of the knob of the specillum [probe]"), ${ }^{57}$ the descriptions are not contradictory. In fact, neither the texts nor our measurements suggest needle placement posterior to the pars plana. Further, it seems unlikely that needle placement posterior to the pars plana (ie, through the peripheral retina) would have resulted in successful outcomes, because the risk of vitreous hemorrhage and retinal detachment would be quite high.

All three authors described the needle entering an "empty space." According to Celsus, arrival at this empty space is heralded by decreased resistance once scleral penetration is complete. ${ }^{38}$ Historians have interpreted the "empty space" mentioned by Celsus ${ }^{1,12}$ and by pseudo-Galen ${ }^{70}$ to be the space between the iris and lens, ie, the posterior chamber. One note about the anatomy of the posterior chamber is relevant. Magnus implied that a needle entering the posterior chamber must have been anterior to the lens. But, as can be seen with imaging or sectioning, typically the anterior-most aspect of the lens lies anterior to the posterior chamber (Figure 10). ${ }^{53}$ Moreover, the most posterior lens zonules, which are bathed in aqueous rather than vitreous, lie posterior to the lens equator. Thus, the posterior chamber lies peripheral, not anterior, to the crystalline lens.

Indeed, with anterior angulation of the needle, it does seem anatomically possible that a needle entering as far posteriorly as the rectus muscles could pass through the ciliary body, the posterior chamber, the iris-lens channel, and into the anterior chamber (Figure 10). The needle could remain posterior to the iris and anterior to the vitreous (Figure 10). A medieval drawing of couching depicted the needle posterior to the iris (Figure 9). More anterior needle entry would also be possible, but, depending on the insertion angle, the needle would contact either the iris or displace the lens before reaching the iris-lens channel.

By mentioning the entry of the needle into the "empty space," these ancient authors were probably most interested in conveying that the operator felt decreased resistance when scleral penetration was complete. ${ }^{38}$ Perhaps these authors can

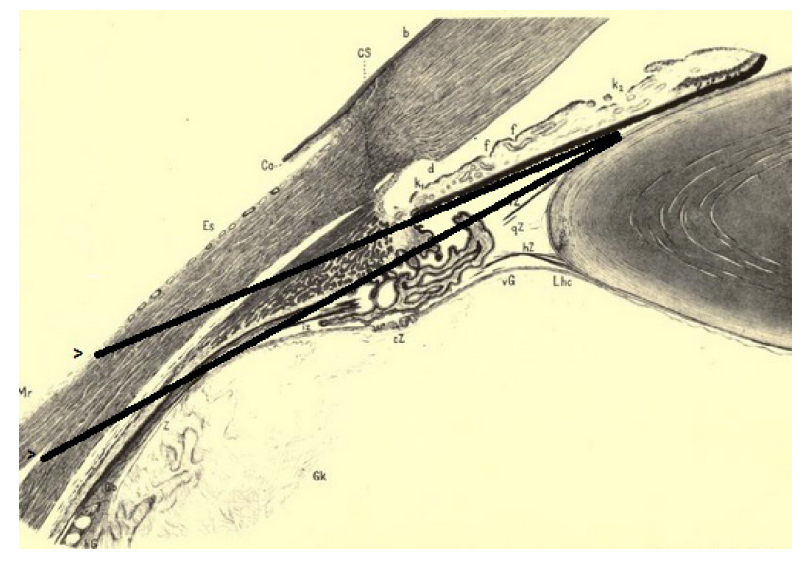

Figure 10 The ciliary region of the eye. ${ }^{37}$

Notes: Added lines show the possibility of a couching needle passing through the sclera (as far posteriorly as the rectus muscle insertion), the ciliary body, the posterior chamber, and the iris-lens channel, while remaining posterior to the iris and anterior to the vitreous. The absolute limbus to rectus muscle distance, and the ciliary body length, are both $20 \%-23 \%$ less in the medial region, depicted here, compared with the lateral region, ${ }^{56}$ which is involved with the couching technique of Celsus, pseudo-Galen, and Paulus Aegineta. Nonetheless, the relative length of internal and external structures is unchanged.

Abbreviations: b, border of Bowman's membrane; $q B$, vitreous base; $C s$, corneoscleral limbus; Co, conjunctiva sclerae; d, Descemet's membrane; Es, episcleral tissue; $f$, contraction furrows; vG, anterior border of the vitreous; hG, posterior border of the vitreous; Gk, vitreous nucleus; kl, ciliary and k2 pupillary crypts; Lhc, ligamentum hyaloideo-capsulare; Mr, medial rectus tendon; $i Z$, innermost; cZ, circular; vZ, anterior; qZ, middle; hZ, posterior zonula fibers; Z, zonular cleft.

be forgiven for neglecting to mention that the needle might traverse the ciliary body. Today, if a surgeon stated "I passed a needle through the sclera overlying the pars plana, and then through the posterior chamber until I saw the needle enter the anterior chamber," we would not infer that the surgeon thought the lens to be located in the center of the eye.

Many historians have accepted Magnus' idea that there were two schools of thought during the ancient Greco-Roman period: a central lens (taught by Celsus and his "contemporaries") and an anterior lens (described by Galen). The fact that Paulus used both Galen's terminology for the cornea-iris-lens complex (iris or stephanen) and described the couching needle entering an empty space (kenembateseos), just as Celsus did, shows that there were not two schools of thought. The couching technique described by Celsus, pseudo-Galen, and Paulus was accepted in antiquity as compatible with an anterior lens.

Although Magnus' statement that Celsus placed the lens centrally has been repeated for over a century, ${ }^{1-18}$ Magnus is the only observer we can find who independently came to this conclusion. The translation by Spencer did not depict a central lens (Figure 2). ${ }^{38}$ Magnus' depiction has been widely accepted in the ophthalmic literature, but our analysis suggests that Spencer's interpretation is consistent with Celsus' descriptions. 
Of course, ancient texts do not accurately describe the microscopic anatomy of the ciliary region, and do have ambiguities regarding needle placement. Moreover, the actual practice of couching might deviate from theoretical designs when operating with the naked eye and ancient instruments on unanesthetized patients. Nonetheless, such ambiguities in theory or practice do nothing to prove that Celsus described the crystalline lens as being located centrally. Magnus made this assumption because an apparently posteriorly placed needle entered the posterior chamber. If we do not know where the needle was intended to be placed, then we cannot state that it was placed posteriorly, and there is no reason to require a central lens. Such ambiguities regarding needle placement would undercut, rather than establish, the veracity of Magnus' assumption.

\section{Medieval Arabic authors}

Our review finds that the idea that the lens is located centrally first appears among the ninth-century Arabic authors in Mesopotamia. For some of these authors, the primary language was Syriac or Persian. Hunain Ibn Is-Haq (AD 809-877), known later as Johannitus, translated many Greek works into Syriac and Arabic. He also understood Persian. Hunain was not known for performing dissections, and does not claim to have studied eye anatomy through dissection. ${ }^{19}$ Rather, he came to prominence largely through his linguistic talent, and was selected by the caliph to direct the libraryacademy known as the House of Wisdom, established in Baghdad in AD 830. ${ }^{19}$

The lens is not described as being in the center of the eye in Hunain's translation of De Usu Partium. ${ }^{36}$ Therefore, Hunain did not misunderstand Galen. However, Hunain did include the central lens repeatedly in his own ophthalmic works. Hunain compiled an ophthalmic tome between AD 860 and 870 from treatises he had composed over the previous 30 years. ${ }^{19}$ Hunain's first treatise, on anatomy, is based largely on Galen's De Usu Partium book X, ${ }^{19}$ but deviated from Galen's ideas in some respects. Hunain is thought to have initially translated De Usu Partium and composed the first treatise between AD 830 and $840 .{ }^{19}$ Hunain mentions the centrality of the lens repeatedly in the first treatise, writing of the "ice-like humour": "It is situated in the middle of the eye, like a point which we imagine to be in the centre of a globe"19 (Figure 11). This teaching also featured prominently at the beginning of a shorter work on the eye often attributed to Hunain: "Where is the location of the glacial humor in the eye? In the center ... It is placed in the center being given the rank that it occupies in relation to the other organs." ${ }^{976}$ Like ancient authors, Hunain held that the lens was the primary seat of vision, and the other parts of the eye merely supported and protected the lens. Hunain wrote that the central position offered the best protection. ${ }^{19,76}$

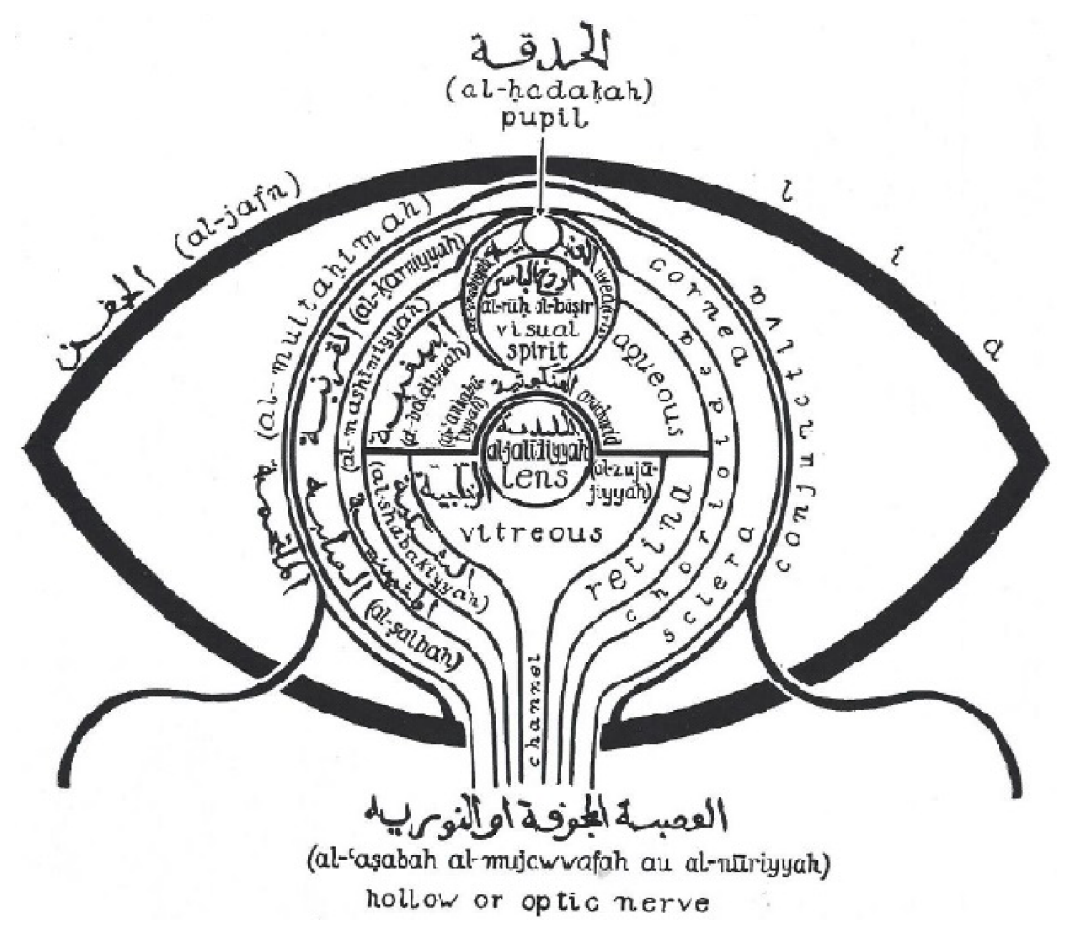

Figure I I Diagram of the eye with a central lens, from Hunain Ibn Ishak's Ten Treatises on the Structure of the Eye (c. AD 860$),{ }^{19}$ taken from an AD I I97 manuscript, as copied and labeled by Polyak. ${ }^{20}$ 
We do not find the statement of the central lens in the writings of Hunain's teacher, Yuhanna ibn Masawaih (AD 777-857), known to later Latin writers as Mesue. .2,77 $^{2}$ Masawaih dissected apes for anatomic study. ${ }^{78}$

The idea of the central lens appears in Arabic writings which cited Hunain. ${ }^{79-83}$ For instance, we have identified the idea of the central lens in the writings from AD 850 of the contemporary scholar, Ali ibn Sahl Rabban Tabari (AD 807-870). ${ }^{79,80}$ Some of these Arabic writings had broad influence because they were subsequently translated into Latin. ${ }^{81-83}$ For instance, Ali ibn Isa el-Kahhal (c. AD 940-1010), known later as Jesu Hali, wrote: "The crystalline body ... is placed in the middle of the eye, marking the central point of the globe ..." ${ }^{\prime 1}$ Likewise, Abu Ali al-Husain Ibn Sina (c. AD 980-1037), known later as Avicenna, ${ }^{82}$ wrote: "The crystalline humor is colorless, clear, and reflects the light ... Its position is in the center of the eye ...." 83

In retrospect, Magnus' hypothesis that Celsus was the source for the idea of the central lens found in the medieval Arabic works is highly unlikely. Hunain was not known to interpret Latin. ${ }^{19}$ Some sources state that Celsus' work was essentially lost during the Middle Ages until discovered in the Vatican Library in the 15 th century ${ }^{84}$ Indeed, the medieval Arabic ophthalmic works ${ }^{19,81-83}$ cited multiple Greek authors, but we cannot find evidence that these authors were familiar with Celsus.

\section{The Renaissance}

The idea of the central position of the lens persisted for over 700 years in anatomical works, such as the 1543 treatise of Andreas Vesalius (LLR 0.53). ${ }^{11,21}$ In 1583, the German oculist Georg Bartisch drew the lens positioned somewhat anteriorly (LLR 0.34), though the accompanying text continued to state that the lens is in the middle of the eye. ${ }^{74}$ Also in 1583, Felix Platter published a diagram with the lens positioned anteriorly (LLR 0.29). ${ }^{22}$ Platter's writings confirmed that the lens was normally located anteriorly. ${ }^{85}$ This correct understanding was perhaps "in the air," because the diagram of the eye by Franciscus Maurolycus (1494-1575) given to a friend before his death and published posthumously in 1611, also had a slightly anterior lens (LLR 0.38)..$^{86,87}$

However, Felix Platter's 1583 description of the anteriorly positioned lens was particularly important, because it was cited by Kepler's 1604 analysis, in which refraction by the lens produced a reversed retinal image. ${ }^{22}$ In the middle of the 17th century, several investigators proposed that the cataract was simply an opacification of the crystalline lens, as opposed to an opacity anterior to the lens. ${ }^{17}$ Extraction of cataracts (as opposed to couching) might have occasionally been performed in the late 17 th century, and certainly was performed in the early 18 th century. ${ }^{17}$ Thus, understanding the true lens position seems to have been a prerequisite for advances in visual physiology and surgery.

\section{Lens centrality and the history of ideas}

What larger lessons can be learned from this analysis? Multiple historians have speculated upon an ancient origin to the idea of the central lens. Meyerhof, Polyak, and Magnus stated that they looked to the ancients as the likely source for the medieval description of lens centrality. We have not come across any historians who even considered the possibility that the idea was original with the medieval Arabic authors. The closest might be Eastwood who noted in Hunain's work "renewed emphasis on the centrality of the lens, which is not to be found in Galen." ${ }^{36}$ The modifier "renewed" suggests an era before Hunain's in which lens centrality was described.

Another lesson seems to be the power of authority to create myth. It seems that a medieval author, perhaps Hunain, originated and promulgated the myth of the central lens, and this teaching was accepted for over 700 years on the basis of his authority. Today, we like to think that we would not accept such a myth because we would demand supporting evidence. Nonetheless, Magnus drew a central lens in his diagram, which was accepted as an accurate depiction of Celsus' anatomy for over 100 years. Magnus and Polyak at least attempted to find something in the ancient works to suggest that Celsus or Galen, respectively, described a central lens. The vast majority of historians have not cited any particular passage to support the idea of an ancient belief in a central lens. Presumably, most authors were simply moved by the authority of historians such as Magnus and Polyak.

\section{Conclusion}

Modern historians have written that the medieval idea of lens centrality arose during antiquity, but have not been able to agree on which particular ancient author or passage established this tradition. In fact, Celsus, Galen, and other ancient Greco-Roman authors who first described the lens did not teach that it was in the center of the eye. Celsus made no specific statement about the anteroposterior position of the lens. Ancient Greek authors dissected the eye, and wrote that the lens was anterior enough to touch the iris and that the lens equator meets other ocular structures at the corneoscleral junction. The centrality of the lens was an influential 
and enduring notion which seems to have originated with the ninth-century Arabic authors in Mesopotamia.

\section{Acknowledgments}

Partially funded by National Institutes of Health (Bethesda, MD, USA) Center Core Grant P30EY014801 and Research to Prevent Blindness (New York, NY, USA) Unrestricted Grant to the University of Miami. The funding organizations had no role in the design or conduct of this research.

\section{Disclosure}

The authors report no conflicts of interest in this work.

\section{References}

1. Magnus H, Waugh RL (translator). Ophthalmology of the Ancients. Part 1. Oostende: J.P. Wayenborgh; 1998:53-143.

2. Magnus H, Waugh RL (translator). Ophthalmology of the Ancients. Part 2. Oostende: J.P. Wayenborgh; 1999:463-469.

3. Wade NJ. A Natural History of Vision. Cambridge: MIT Press; 1998:71.

4. Wade NJ. Perception and Illusion: Historical Perspectives. Dordrecht: Springer Science \& Business Media; 2005:63.

5. Chinn H, Bellows JS. The history of the crystalline lens. $Q$ Bull Northwest Univ Med Sch. 1941;15(3):174-188.

6. Duke-Elder S. System of Ophthalmology: The Anatomy of the Visual System. London: Kimpton; 1961:14.

7. Snyder C. Aurelius Cornelius Celsus on Cataracts. Arch Ophthalmol. 1964;71:144-146.

8. Rucker CW. Cataract: a historical perspective. Invest Ophthalmol Vis Sci. 1965;4:377-383.

9. Albert DM. Greek, Roman, and Arabian ophthalmology. In: Albert DM, Edwards DD, editors. The History of Ophthalmology. Cambridge, MA: Blackwell Science; 1996:23.

10. Lovicu FJ, Robinson ML, editors. Development of the Ocular Lens. Cambridge: Cambridge University Press; 2004:6.

11. Bobrow JC, Beardsley TL, Jick SL, et al. Lens and Cataract. 2012-2013. San Francisco: American Academy of Ophthalmology; 2013:3-4.

12. Hirschberg J, Blodi FC (translator). The History of Ophthalmology. Vol. 1. Antiquity. Bonn: J.P. Wayenborgh Verlag; 1982:100-248.

13. Shastid TH. History of ophthalmology. In: Wood CA, editor. The American Encyclopedia and Dictionary of Ophthalmology. Vol. XI. Chicago: Cleveland Press; 1913:8580-8588.

14. Fronimopoulos J, Lascaratos J. The terms glaucoma and cataract in the ancient Greek and Byzantine writers. Doc Ophthalmol. 1991;77: 369-375.

15. Enoch JM. The history of ophthalmology. Optometry Vis Sci. 1997;74(9): 699-700.

16. Kovacs J, Unschuld PU. Essential Subtleties on the Silver Sea: The Yin-Hai Jing-Wei: A Chinese Classic on Ophthalmology. Berkeley: University of California Press; 1998:62.

17. Jampel RS. The four eras in the evolution of cataract surgery. In: Kwitko ML, Kelman CD, editors. The History of Modern Cataract Surgery. The Hague: Kugler; 1998:19-21.

18. Mark HH. Aqueous humor dynamics in historical perspective. Survey Ophthalmol. 2010;55(1):89-100.

19. Hunain Ibn Is-Haq (Johannitus), Meyerhof M (translator). The Book of the Ten Treatises on the Eye Ascribed to Hunain Ibn Is-Haq (809-877 A.D.). Cairo: Government Press; 1928:X-125.

20. Polyak SL. The Retina. Chicago: University of Chicago Press; 1941: 98-135.

21. Polyak SL. The Vertebrate Visual System. Chicago: University of Chicago Press; 1968:11-31.
22. Lindberg DC. Theories of Vision: From Al-Kindi to Kepler. Chicago: University of Chicago Press; 1976:34-208.

23. Lindberg DC. Medieval Islamic achievement in optics. Opt Photon News. 2003;14(7):30-35. Available from: http://campus.udayton. edu/ physics/rjb/PHY\%20108\%20Articles/Islamic\%20Optics\%20 Achievements.pdf. Accessed November 15, 2015.

24. Finger S. Origins of Neuroscience: A History of Explorations into Brain Function. Oxford: Oxford University Press; 1994:69-71.

25. Howard IP, Rogers BJ. Binocular Vision and Stereopsis. New York: Oxford University Press; 1995:5.

26. Howard IP. Perceiving in Depth. Volume 1: Basic mechanisms. New York: Oxford University Press; 2012:16.

27. Edwards D. Eye movements and neuro-ophthalmology. In: Albert DM, Edwards DD, editors. The History of Ophthalmology. Cambridge: Blackwell Science; 1996:263.

28. Realini T. Book review. J Glaucoma. 1998;7(3):221-222.

29. Glaser JS. Romancing the chiasm: vision, vocalization, and virtuosity. J Neuroophthalmol. 2008;28(2):131-143.

30. Zipser B. Deleted text in a manuscript. Galen on the eye and the Marc. Gr. 276. Galenos. 2009;3:107-112.

31. De Laey JJ. The eye of Vesalius. Acta Ophthalmol. 2011;89(3): 293-300.

32. Grzybowski A, Sak J, Pawlikowski J. The history of scientific concepts of vision in relation to Ludwik Fleck's thought-styles. Acta Ophthalmol. 2013;91(6):579-588.

33. Mailer CM. Glaucoma. An argument that began with Aristotle. Arch Ophthalmol. 1966;76(4):623-626.

34. Crone RA. A History of Color: The Evolution of Theories of Lights and Color. Dordrecht: Kluwer Academic; 1999:np.

35. Kalloniatis M, Luu C. Principles of vision. In: Kolb H, Fernandez E, Nelson R, editors. Source Webvision: The Organization of the Retina and Visual System. Salt Lake City, UT: University of Utah Health Sciences Center; 1995-2005 May 1 [June 4, 2007]. Available from: http://www. ncbi.nlm.nih.gov/pubmed/21413377. Accessed November 15, 2015.

36. Eastwood BS. The elements of vision: the micro-cosmology of Galenic Visual Theory according to Hunayn Ibn Ishāq. Trans Am Philos Soc. 1982;72:1-59.

37. Salzmann M, Brown EVL (translator). The Anatomy and Histology of the Human Eyeball in the Normal State: Its Development and Senescence. Chicago: University of Chicago Press; 1912:3.

38. Celsus C, Spencer WG (translator). De Medicina. Vol. 3. London: William Heinemann Ltd; 1938:346-351. Available from: https:// archive.org/stream/demedicina03celsuoft\#page/348/mode/2up. Accessed August 20, 2015.

39. Von Staden H. Herophilus: The Art of Medicine in Early Alexandria. Cambridge: Cambridge University Press; 1989:36-578.

40. Wiltse LL, Pait TG. Herophilus of Alexandria (325-255 B. C.): The father of anatomy. Spine. 1998;23(17):1904-1914.

41. Rufus d'Éphèse, Daremberg C, Ruelle C (translators). Oeuvres de Rufus d'Éphèse. Paris: Imprimerie Nationale; 1879:135-172. Available from: http://www2.biusante.parisdescartes.fr/livanc/index. las? cote $=36058 \& \mathrm{p}=194 \& d o=$ page. Accessed August 20, 2015.

42. Leffler CT, Schwartz SG, Hadi TM, Salman A, Vasuki V. The early history of glaucoma: the glaucous eye ( $800 \mathrm{BC}$ to $1050 \mathrm{AD})$. Clin Ophthalmol. 2015;9:207-215.

43. Bujalková M. Rufus of Ephesus and his contribution to the development of anatomical nomenclature. Acta Med-Hist Adriat. 2011;9(1); $89-100$.

44. Gersh CJ. Naming the Body: A Translation with Commentary and Interpretive Essays of Three Anatomical Works Attributed to Rufus of Ephesus [PhD dissertation]. Ann Arbor, MI: University of Michigan; 2012. Available from: http://deepblue.lib.umich.edu/ bitstream/handle/2027.42/95946/cgersh_1.pdf?sequence=1. Accessed November 11, 2015.

45. Young L. The Father of Anatomy: Galen and His Dissections. Berkeley Heights, NJ: Enslow Publishers; 2010:53. 
46. Nuland SB. Doctors: The Biography of Medicine. 2nd ed. New York: Vintage Books; 1995:47.

47. Galen, May MT (translator). On the Usefulness of the Parts of the Body. De usu partium. Vol. 2. Ithaca, NY: Cornell University Press; 1968: 463-479.

48. Galen, Duckworth WL (translator). On Anatomical Procedures. The Later Books. Cambridge: University Press; 1962:40-43.

49. Lapuerta P, Schein SJ. A four-surface schematic eye of macaque monkey obtained by an optical method. Vision Res. 1995;35(16):2245-2254.

50. Gross CG. Galen and the squealing pig. Neuroscientist. 1998;4: 216-221.

51. Sanchez I, Martin R, Ussa F, Fernandez-Bueno I. The parameters of the porcine eyeball. Graefes Arch Clin Exp Ophthalmol. 2011;249(4): 475-482.

52. Hilloowala R. Leonardo da Vinci, visual perspective and the crystalline sphere (lens): if only Leonardo had had a freezer. Vesalius. 2004;10: $10-15$.

53. Pradhan S, Leffler CT, Wilkes M, Mahmood MA. Preoperative iris configuration and intraocular pressure after cataract surgery. J Cataract Refract Surg. 2012;38(1):117-123.

54. Leffler CT, Giliberti FM, Vasuki V. Cataract extraction and the iris configuration. Ophthalmology. 2013;120(6):e29-e30.

55. Silver DM, Quigley HA. Aqueous flow through the iris-lens channel: estimates of differential pressure between the anterior and posterior chambers. J Glaucoma. 2004;13(2):100-107.

56. Aiello AL, Tran VT, Rao NA. Postnatal development of the ciliary body and pars plana. A morphometric study in childhood. Arch Ophthalmol. 1992;110:802-805.

57. Paulus Aegineta, Adams F (translator). The Seven Books of Paulus Egineta. Vol. 2. London: Adlard; 1846:278-280. Available from: https://archive.org/stream/sevenbooksofpaul02pauluoft\#page/278/ mode/2up. Accessed November 12, 2015.

58. Paulus Aegineta, Libri V-VII. Heiberg JL (editor), Corp. Med. Graec. IX 2, Leipzig et Berlin; 1924:59-61. Available from: http://cmg.bbaw. de/epubl/online/cmg_09_02.php. Accessed November 12, 2015.

59. Crane GR (editor). Autenrieth Lexicon. Perseus Digital Library; 2015. Available from: http://www.perseus.tufts.edu/hopper/morph?l=stefa \%2Fnhn\&la=greek\&prior=ou)\#Perseus:text:1999.04.0073:entry=stef a/nh-contents. Accessed November 12, 2015.

60. Stephanon. Strong's concordance. Available from: http://biblehub.com/ greek/stephanon_4735.htm. Accessed November 13, 2015.

61. Oribasius, Bussemaker C, Daremberg C (translators). Oeuvres d'Oribase. Vol. 3. Paris: 1858:294-304. Available from: http:/gallica bnf.fr/ark:/12148/bpt6k28927t/f326.image. Accessed August 20, 2015.

62. Aetius of Amida, Hirschberg J, Waugh RL (translators). The Ophthalmology of Aetius of Amida. Belgium: Wayenborgh; 2000:2-85.

63. Paulus of Aegina, Adams F (translator). The Medical Works of Paulus Egineta. Vol. 1. London: J. Welsh; 1834:273. Available from: https://books.google.com/books?id=sTpfAAAAcAAJ\&pg=P A388\&lpg=PA388\&dq=galen+sclerophthalmia\&source $=$ b1\&ots $=-$ TXg1hqZF_\&sig=LE_1Lnxg3O2rEuh1s_bVAUse4UU\&hl=en\&sa= X\&ved=0CCUQ6AEwAWoVChMIj5ibxPX5xgIVxI4NCh2Q1w-G\# $\mathrm{v}=$ onepage $\& \mathrm{q}=$ crystalline $\& \mathrm{f}=$ false. Accessed August 20, 2015.

64. Theophilus Protospatharius, Greenhill WA (editor). De corporis humani fabrica. Book IV. Oxford: Oxonii Typographeum Academicam; 1842:150-173. Available from: https://books.google.com/ books?id=CHA-AAAAcAAJ \&q=crystalline $\# \mathrm{v}=$ onepage $\& \mathrm{q}=$ crystalli ne\&f $=$ false. Accessed August 20, 2015.

65. Leffler CT, Schwartz SG. John Thomas Woolhouse (1666-1734): Bold ophthalmic innovator and teacher. In: Proceedings of the Cogan Ophthalmic History Society; 2014; Monterey, CA:57-79.

66. Woolhouse JT. A Treatise of the Cataract and Glaucoma: In Which the Specific Distinctions of Those Two Diseases, and the Existence of Membranous Cataracts, Are Clearly Demonstrated. London: Printed for M. Cooper; 1745:1-127.
67. Celsus, Greive J (translator). Of Medicine. London: Wilson; 1756:404. Available from: https://archive.org/stream/acorneliuscelsus00cels\#page/404/mode/2up. Accessed August 20, 2015.

68. Celsus, Lee A (translator). Celsus, on medicine. In: Eight Books. Vol. 2. London: E. Cox; 1831:257-261. Available from: https://books. google.com/books?id=MAMPAQAAIAAJ\&pg=RA1-PA164\&dq= inauthor:celsus+suffusio \&hl=en\&sa $=X \&$ ei $=\mathrm{hC} 8 \mathrm{OVfzxIMakNvy3h}$ Bg\&ved $=0$ CCQQ6AEwAQ\#v=onepage $\& q=$ inauthor $\% 3$ Acelsus $\% 2$ 0suffusio\&f=false. Accessed August 20, 2015.

69. Leffler CT, Schwartz SG, Stackhouse R, Davenport B, Spetzler K. Evolution and impact of eye and vision terms in written English. JAMA Ophthalmol. 2013;131(12):1625-1631.

70. Lascaratos J, Marketos S. The cataract operation in ancient Greece. Hist Sci Med. 1982;17(Spec 2):317-322. Available from: http:// www.biusante.parisdescartes.fr/sfhm/hsm/HSMx1982x017xspec2/ HSMx1982x017xspec2x0317.pdf. Accessed November 15, 2015.

71. pseudo-Galen. Introductio, seu medicus. In: Galien, Kuhn CG, editor. Galeni Opera Omnia. Vol. 14. Leipzig: Car. Cnoblochii; 1827:784. Available from: http://www.biusante.parisdescartes.fr/histoire/medica/ resultats/index.php? cote $=45674 \times 14 \& \mathrm{p}=786 \&$ do $=$ page. Accessed October 26, 2015.

72. pseudo-Galen. Introductio Seu Medicus. A Digital Corpus for Graeco-Arabic Studies. 2015:784. Available from: http://www.graecoarabic-studies.org/single-text/text/kuehn-100/page/784.html. Accessed October 26, 2015.

73. Leffler CT, Schwartz SG, Davenport B, Randolph J, Busscher J, Hadi T. Enduring influence of Elizabethan ophthalmic texts of the 1580s: Bailey, Grassus, and Guillemeau. Open Ophthalmol J. 2014;30:12-18.

74. Bartisch G, Blanchard DL (translator). Ophthalmodouleia. That is the Service of the Eyes. Ostend, Belgium: JP. Wayenborgh; 1995:7-63.

75. Mattern SP. Galien, Tome III: Le médecin: introduction. Med Hist. 2011;55(2):252-253. Available from: http://www.ncbi.nlm.nih.gov/ pmc/articles/PMC3066665/. Accessed October 26, 2015.

76. Hunain Ibn Is-Haq (Johannitus), Sbath RPP, Meyerhof M (translators). Le Livre des Questions sur L'Oeil de Honain Ibn Ishaq. In: Memoires Presentes a L'Institut d'Egypte. Vol. 36. Cairo: Institut Francais d'Archeologie Orientale; 1938:83.

77. Prüfer C, Meyerhof M. Die Augenheilkunde des Jûhannā b. Mâsawaih (777-857 n. Chr.) In: Sezgin F, editor. Yuhanna Ibn Masawayh (d. 243/857). Texts and Studies. Frankfurt: Goethe University; 1996:217-268

78. Shoja MM, Tubbs RS. The history of anatomy in Persia. $J$ Anat. 2007; 210(4):359-378

79. 'Alī ibn Sahl Rabbān Tabarī, Muhammad Zubair Siddiqi (editor). Firdausu'l-Hikmat; or Paradise of Wisdom. Berlin-Charlottenburg: Sonnen Druckerei G.M.B.H.; 1928:160.

80. Meyerhof M. `Alî at-Tabarî's "Paradise of Wisdom", one of the oldest Arabic Compendiums of Medicine. Isis. 1931;16(1):6-54.

81. ibn Isa el-Kahhal A (Jesu Hali), Wood CA (translator). Memorandum Book of a Tenth-Century Oculist. Chicago: Northwestern University; 1936:12-13.

82. Ibn Sina AA (Avicenna), Hirschberg J, Lippert J (translators). Die Augenheilkunde des Ibn Sina. Leipzig: Verlag von Veit; 1902:12. Available from: https://archive.org/details/dieaugenheilkund00avic. Accessed August 20, 2015.

83. Stricker L. A historical review of the development of the cataract operation. J Ophthalmol Otolaryngol. 1909;3(10):403-413. Available from: https://books.google.com/books?id=ImEsAAAAYAAJ\&pg=PA40$3 \& 1$ g $=$ PA $403 \& \mathrm{dq}=$ herophilus $+\% 22$ center + of + the + eye $\% 22+$ eye + lens+-galen+-celsus\&source $=$ bl\&ots $=15 \mathrm{Hj} 5 \mathrm{jP} 69 \mathrm{i} \&$ sig=qjKjorwhn Z2cZJph1GIlQnatSFA\&hl=en\&sa=X\&ved=0CB4Q6AEwAGoVC hMIIZDE9Kr3xgIVyryACh0r-wfc\#v=onepage $\& \mathrm{q}=$ herophilus $\% 20$ $\% 22$ center $\% 20$ of $\% 20$ the $\% 20$ eye $\% 22 \% 20$ eye $\% 20$ lens $\% 20$-galen $\% 2$ 0 -celsus\&f=false. Accessed August 22, 2015.

84. Dirckx JH. Dermatologic terms in the De Medicina of Celsus. Am J Dermatopathol. 1983;5(4):363-370. 
85. Leffler CT, Schwartz SG, Giliberti FM, Young MT, Bermudez D. What was glaucoma called before the 20th century? Ophthalmol Eye Dis. 2015;7:21-33.

86. Maurolycus F. Photismi de lumine. Neapoli: T. Longi; 1611: 71. Available from: https://books.google.com/books?id=Ug6ywn-D9BgC\&prin tsec $=$ frontcover\&source $=$ gbs_ge_summary_r\&cad $=0 \# v=$ onepage $\& q \&$ $\mathrm{f}=$ false. Accessed November 12, 2015.
87. Maurolycus F, Crew H (translator). The Photismi de lumine of Maurolycus; a chapter in late medieval optics. New York: The Macmillan Company; 1940:108.

\section{Publish your work in this journal}

Clinical Ophthalmology is an international, peer-reviewed journal covering all subspecialties within ophthalmology. Key topics include: Optometry; Visual science; Pharmacology and drug therapy in eye diseases; Basic Sciences; Primary and Secondary eye care; Patient Safety and Quality of Care Improvements. This journal is indexed on

\section{Dovepress}

PubMed Central and CAS, and is the official journal of The Society of Clinical Ophthalmology (SCO). The manuscript management system is completely online and includes a very quick and fair peer-review system, which is all easy to use. Visit http://www.dovepress.com/ testimonials.php to read real quotes from published authors. 